\title{
Risk analysis and countermeasures for international trade under the economic downturn pressure
}

\author{
Fang Fengxia \\ Meizhouwan Vocational Technology College
}

Keywords: economic downturn; international trade; analysis and countermeasures;

\begin{abstract}
International trade is as the powerful support for economic development, thus, how to prevent risks in the economic downturn and realize the positive interaction between economic and trade are the main problems to be solved in this field. Therefore, in this paper, the connotation, characteristic and predictability of international trade risk are introduced firstly, to analyze the trade risk easily formed in economic downturn. According to the characteristics of international trade in our country, from four aspects of political risk, market risk and others, the faced risks of international trade enterprises are pointed out, and based on this, some suggestions on how to effectively anticipate and avoid risks in international trade are put forward.
\end{abstract}

\section{Introduction}

Since the reform and opening up, China's macro economy has experienced a period of rapid development, but since the 2008 financial crisis, in the case of the slowdown in the world economy and the lack of external demand, China's economic grows slowly, and enters to the soft landing process and a period of high incidence of trade friction [1-3]. The traditional trade methods has been difficult to adapt to the pattern of trade in the world, and exports face serious trade barriers, it has seriously affected the development of China's foreign trade, but also increased a huge negative impact on the economic efficiency of enterprises [4-6]. In this case, it is necessary to analyze and discuss the risks of international trade under the economic downturn pressure in the current period [7-9], to find feasible solutions and measures in order to promote the development of China's economic and trade [10].

\section{Economic downturn is easy to form a trade risk analysis}

\section{1 the connotation and characteristics of international trade risk}

International trade risk refers to the risk in the process of international trade, including policy risk, operational risk and exchange rate risk. International trade risk is objective existence, and foreign trade enterprises in the international trade business processes often have to face various risks, thus, to positively analyze the characteristics, generating rules and avoiding methods of international trade risk has important significance to promote the healthy development of international trade.

International trade risk has the following characteristics: (1) the objective existence. That international trade risk is objective existence, and not to transfer to the personal will. Because of the impacts of asymmetric information, operation mistake and the understanding deviation, international trade risks almost cannot be completely avoided; (2) the relative variability. The international trade risk changes with time and space. This is because of altered with the change of time and space, social environment, cultural environment, political environment and legal environment are changed. And the educated level, spending power and consumer preferences of people are all affected by the changes. Enterprise's awareness of risk early warning also increased or weakened, which in a certain extent determines the performance of enterprise's ability of risk prevention and control in international trade; (3) unconscious. The generation of international trade risk is caused by the unconscious behavior of trade body, the trade body is as the leader of international trade, and the understanding deviation, decision-making mistakes, and operation error 
may cause the occurrence of the international trade risk. In other words, the international trade risk does not include the situation of malicious or intentional behavior, that is, the occurrence of international trade risk is difficult to predict, which is generated in the unconscious.

2.2 foreseeability of international trade risk

The timely prediction of international trade risk is of great significance to develop scientific risk prevention and control measures. And the key to predict international trade risk lies in the timely identification and judgement of the type of risk and the occurrence possibility of the risk. In the competition of international market, the volatility of commodity prices is inevitable, so foreign trade enterprises only fully aware of the reason and the possibility of price fluctuation, the price risk can be effectively foreseen, the of rational judgment and classification can be made, and then the appropriate response measures are taken. In international trade, the prediction of price risk mainly refers to the identification, judgment and prediction of the following risks.

(1) Consumer risk. Consumer is one of the biggest factors in international trade and market demand. As the starting point and the final destination of foreign trade enterprises participating in all international trade activities, the complexity of consumer's preferences and behaviors directly determines the uncertainty of market demand in international trade. Foreign trade enterprises only have a full understanding of the target consumer's cultural background, consumer preferences, and customs and so on, the risk of consumers in international trade can be predicted in a timely manner.

(2) Market development risk. Foreign trade enterprises usually lack a comprehensive understanding of the target market, resulting in that the development of the market will not reach the established goals, and then bring the corresponding risk. To foresee the risk, the enterprise must invest sufficient talents and energy in market research.

(3) The risk of attracting demand. Enterprises in order to attract the seller to buy the product, often make the promises of "Three Guarantees for quality", "Cash on Delivery" and others, if it cannot be done, it will damage corporate image. To fully understand the trade demand and credit conditions, it also pays close attention to its ability to perform.

2.3 economic downturn is easy to form a trade risk

(1) The decline in the domestic economy has increased the risk of trade credit. Economy is in the down state, the production and management of foreign trade enterprises will face difficulties. The existence of capital chain rupture risk, less profits, untimely loans repaying, will affect the bank's operating conditions, it is difficult for the bank to profit, and the credit capital turnover efficiency is also insufficient, thus, the liquidity of financial assets is affected.

(2) There is a huge risk of local debt. The current financial situation of China's local government is not optimistic. According to the data of the National Audit Office, to June 2013, in the debt that local government has the responsibility to repay, there is a 1.86 billion yuan debt to repay in 2015. After June 2013, the debt of local government is added to repay, there are 850 billion yuan in 2015 to repay. At present, the gap of the two batch of local debt which can be replaced and the incremental part of the local debt is still 700 billion yuan. However, the government and the financing platform companies borrow from each other, once the financing environment has further tightened during a certain period of time, the financing platform company cannot repay debt, the total debt will be like a snowball as accumulate, thereby increasing the possibility of bringing the systematic trade and financial risk.

(3) The downturn trade in the real estate market brought local financial pressure. The past two years, China's real estate market is downturn, which causes the inability to repay loans, reduced financing needs and other situations, thereby triggering a large amount of financial risks. More worrisome is that in financial risks triggered by the real estate market, the larger risk does not in banks and other financial institutions.

(4) Lower interest rates affect the profitability of banks and other financial institutions. In recent years, China has been the phenomenon of capital outflows, domestic liquidity is passively constrained, so the Central bank needs to take some measures to manage liquidity, such as cutting to reserve to offset the impact of liquidity. After 2008, Central Bank has repeatedly lowered the benchmark interest rates for bank deposits and loans. The current change of benchmark interest rate 
is less than the change of loan interest rate, which leads to a decrease in net interest margin, and the profitability will be affected, resulting in a risk of reduction in net interest margin.

\section{3 measures to deal with the risks of international trade enterprises}

\subsection{The faced risk of international trade enterprises}

The political risk is largely determined by the political stability of the country where the business operates, and the local political system. Change of government, and sometimes will lead to significant changes in business. Even in countries with a stable political system, the impact of political reform may be significant.

Market risks, sometimes become financial risk or price risk, that is, the risk of loss due to changes in the market. The main market risk faced by international trade enterprises is exchange rate risk and commodity price risk. The risk of exchange rate risk is the possibility of exchange rate fluctuation, and the possibility of a change in the value of one currency to another. The major commodity prices of the enterprises are surprisingly volatile, and it is also possible that foreign trade enterprises are facing huge risks.

Operational risk is the risk of loss due to the physical effects of employees, processes, infrastructure or technology or similar factors that affect the operation. The operational risks faced by foreign trade enterprises are mainly not to understand or misuse of the terms of trade in some international trade contracts. Terms of trade is the special expression of the terms in the trade contract. In international trade, if the operation of the trade term is not properly, it is easy to bring huge operational risks to the enterprise.

Policy risk is due to the increasing trade friction between countries, anti-dumping cases and the existence of technical trade barriers. Economic globalization makes the goods can be more smooth transfer in different countries, however, continued weakness in Europe and the United States economy in recent years, trade protectionism have gradually rising trend, which also makes the foreign trade enterprises facing the further intensified policy risk.

\subsection{The proposal for international trade enterprises to deal with the risk}

\section{To implement the credit information investigation of transaction object}

In international trade, it is very important to choose a good deal, which is the precondition to avoid trade risk. It must be careful to examine the authenticity of the other side of the enterprise, and identify each other's credit situation. The main content of the credit investigation includes: firstly, to check the original and copy of the other business license, and verify its operating activities, goods, registered capital, legal address and whether it is now still in the legitimate business activities.

2 To establish the internal control decision-making mechanism of risk

Any enterprise in the process of international trade, there is a certain risk. The so called risk management, just is to find an appropriate ratio of distribution in the course of trade between the benefit of and existing risks. To enable the enterprise to obtain the biggest benefit in the trade, it is necessary to grasp trade risk well, which requires enterprises to balance the pros and cons to choose something at the same time to give up certain benefits, because the benefits and risks always coexist. Enterprise is best not to do beyond the ratio of benefit and risk in trade.

3 effectively improving the quality of export products

Today, the competition in the international market has changed from price competition to quality competition, enterprises should rely on scientific and technological progress, and pay attention the application of scientific and technological achievements in production, constantly open up new products, and improve product quality, grade and processing depth. In the face of international technical trade barriers and increasing "international standard", the export enterprises of our country should fight back with the quality of the products, strive to improve the standard of quality in our country, build brands, and enhance the international competitiveness of products.

4 strict following the international trade practices

The international trade practice is usually the general principles, rules and regulations of international trade established by the international organizations or business groups. It has been well 
known to the trade and banking circles of most countries, and is widely accepted and applied. Enterprises in the contract signing, goods delivery, payment process should be strictly according to the basic operation procedures of the import and export trade, adhere to the use of bank credit to complete the payment settlement, correctly handle the relationship between good contract, letter of credit, single grab and goods, especially the relationship between credit and single grab, to make "consensus document", "only consistent" and guarantee the payment timely liquidation.

5 full use of derivative financial instruments

risk management of financial derivative tools refers to that the parties involved in financial derivatives tools identify, measure and control the risk of the transaction process, which can obtain enough security for a variety of activities and methods with the minimum cost. To carry out effective risk management and control of financial derivatives tools is the necessary condition and important guarantee for financial institutions and investors to conduct financial derivatives transactions.

In participating in the overseas derivatives transactions, enterprises can choose the financial institutions with a high credit rating as a partner, it not only can avoid the risk, but also the partners can provide useful advice for the enterprises; in the interior of enterprises, check and balance mechanism should be established, to prevent unauthorized operation, and make risk control; using the risk value evaluation method, the risk assessment and analysis of derivative financial instruments is carried out; using scientific means, the risk management of financial instruments is performed.

\section{Conclusions}

In view of the greater financial risk brought by domestic economy continued downturn, in this paper, the connotation, characteristic and predictability of international trade risk are introduced firstly, to analyze the trade risk easily formed in economic downturn. According to the characteristics of international trade in our country, from four aspects of political risk, market risk and others, the faced risks of international trade enterprises are pointed out, and based on this, some suggestions on how to effectively anticipate and avoid risks in international trade are put forward.

\section{References}

[1] Liu Fei, Hu Mingxing, Hu Yanjie. Prediction of Chinese timber supply and demand and import trade under the background of forest reform: a spatial equilibrium analysis based on CGTM model [J]. World forestry research, 2015, 28 (3): 53-56.

[2] Han Yanling, Chen Sanjing. Prediction analysis of economic development of Kazakhstan level based on ARIMA model [J]. Journal of Urumqi Vocational University, 2015, 24 (2): 27-31.

[3] Liu Fei, Hu Mingxing, Hu Yanjie. Prediction of Chinese timber supply and demand and import trade under the background of forest reform: a spatial equilibrium analysis based on CGTM model [J]. World forestry research, 2015, 28 (3): 53-56.

[4] Zeng Xiangyu. Polynomial prediction model and its application based on RLS algorithm [J]. Economic mathematics, 2014, 31 (1): 85-89.

[5] Zeng Hui. Research and Simulation of the construction cost estimation of mixed economic model [J]. Computer simulation, 2015, 32 (3): 430-433.

[6] Hu Jiangxia, Wen Chuanhao, Lan Xiujuan. Analysis and forecast of ecological pressure of economic sustainable development in the Three Gorges Reservoir Area -- based on the grey prediction model [J]. Technology economy, 2015, 34 (9): 55-60.

[7] Zheng Chijian, Zhang Yachang, Xiang Yao Qi. Prediction of inbound tourism revenue in China based on combination forecasting model [J]. Journal of Hunan College of Finance and Economics, 2014, 30 (4): 71-77.

[8] Liu Xiaohua, Gao Zishen, Wang Liansheng, et al. Prediction model of relative retention time and physical and chemical properties of PCBs in gas chromatography [J]. Environmental chemistry, 2015, 26 (2): 184-191. 
[9] Liu Yuli, Jiang Yuqiu, Pang Xiuli. The mathematical model of economic analysis of the cost and supply and demand of [J]. Journal of Hengshui University, 2015, 17 (4): 4-5.

[10] Zhang Jingxian, Yang Yingdong, Qian Feng. Research on GNSS/INS error feedback correction based on Calman filter and neural network prediction [J]. Electronic design engineering, 2015, 23 (10): 103-105. 